\title{
Carbon stocks in tree biomass and soils of German forests
}

\author{
Nicole Wellbrock*, Erik Grüneberg, Thomas Riedel, Heino Polley \\ Thünen Institute of Forest Ecosystems Alfred-Möller-Str. 1, Haus 41/42, 16225 Eberswalde, Germany
}

\begin{abstract}
Close to one third of Germany is forested. Forests are able to store significant quantities of carbon (C) in the biomass and in the soil. Coordinated by the Thünen Institute, the German National Forest Inventory (NFI) and the National Forest Soil Inventory (NFSI) have generated data to estimate the carbon storage capacity of forests. The second NFI started in 2002 and had been repeated in 2012. The reporting time for the NFSI was 1990 to 2006. Living forest biomass, deadwood, litter and soils up to a depth of $90 \mathrm{~cm}$ have stored $2500 \mathrm{t}$ of carbon within the reporting time. Over all $224 \mathrm{t} \mathrm{Cha}^{-1}$ in aboveground and belowground biomass, deadwood and soil are stored in forests. Specifically, $46 \%$ stored in above-ground and below-ground biomass, $1 \%$ in dead wood and $53 \%$ in the organic layer together with soil up to $90 \mathrm{~cm}$. Carbon stocks in mineral soils up to $30 \mathrm{~cm}$ mineral soil increase about $0.4 \mathrm{t} \mathrm{Cha}^{-1} \mathrm{yr}^{-1}$ stocks between the inventories while the carbon pool in the organic layers declined slightly. In the living biomass carbon stocks increased about $1.0 \mathrm{t} \mathrm{C} \mathrm{ha}^{-1} \mathrm{yr}^{-1}$. In Germany, approximately 58 mill. tonnes of $\mathrm{CO}_{2}$ were sequestered in 2012 (NIR 2017).
\end{abstract}

Key words: forests ecosystems; soil; carbon stocks; Germany; National Forests Inventory; National Forests Soil Inventory

Editor: Bohdan Konôpka

\section{Introduction}

Forests influence the global climate in many ways (Bonan 2008). One important point of interest is the service of forests as carbon (C) sink. Forest ecosystems store more than $80 \%$ of all terrestrial aboveground $C$ and more than $70 \%$ of all soil organic carbon (Batjes 1996; Jobbagy \& Jackson 2000; Six et al. 2002). Forests are set apart by the fact that carbon is stored long-term in wood. Moreover, biomass enters forest soils as dead leaves, exudates, roots, wood or animal wastes. A portion of this biomass is converted into various carbon compounds through the metabolic activity of microorganisms. The amount of carbon stored in soil is determined by the net balance of the input from organic matters in the soils and its breakdown by microbes. The rates of tree growth and timber harvesting or natural drain determine the carbon storage capacity in living biomass and deadwood.

Many countries used National Forest Inventories to calculated carbon stocks and sequestration in biomass and dead wood (Vidal et al. 2016; Tomppo et al. 2010). However, estimates of national-wide carbon pools and fluxes from repeated soil inventories or monitoring are still the exception (Bellamy et al. 2005).

The importance of forest soils for the carbon cycle is expected to be more increasing in the future (Liski et al. 2002). Many studies confirm that management practices (Kowalski et al. 2004), age structure (Kowalski et al. 2004; Loustau et al. 2004; Magnani et al. 2007), nitrogen (N) deposition (Magnani et al. 2007) and changes in $\mathrm{CO}_{2}$ and climate influence the accumulation of carbon in biomass (Spieker et al. 1996) as well as in soils (Hagedorn et al.2003). Therefore, the German government decided to report on Greenhouse gas emissions as Kyoto Protocol Article 3.4 required optionally. The national inventories are an important basis for the annual greenhouse gas reporting under the Kyoto Protocol and under the United Nations Framework Convention on Climate Change (UNFCCC, sector LULUCF). When litter and mineral soil as carbon pools are involved in the key categories (see Good Practice Guidance, IPCC 2003), reporting has to be made with increased accuracy and effort in the context of the Kyoto Protocol. As a Party of the UNFCCC, since 1994 Germany has been obliged to prepare and regularly update national emission inventories of greenhouse gases.

The current status and development of carbon pools in living biomass, deadwood, soils and litter (the organic layer) are all components of the inventories and have been reported for the period from 1990 to 2012. There are three National Forest Inventories (NFI) and a special Carbon Inventory Study at a NFI subsample surveying living bio- 
mass and deadwood and two NFSI surveying forest soils. The projected rates of change in carbon stocks, based on data from the NFI and the NFSI, are shared with the Federal Environment Agency and summarised in yearly National Inventory Reports (FEA 2017).

The presented results show the considerable contribution of forests to carbon sequestration. Furthermore the article focuses on how much carbon is stored in the different components of the forest ecosystem such as living biomass or soil and how fast the various carbon pools change.

\section{Material and methods}

\subsection{National Forest Soil Inventory}

The National Forest Soil Inventory (NFSI) follows a systematic sampling protocol based on an $8 \mathrm{~km} \times 8 \mathrm{~km}$ grid. Inventories were conducted across Germany in the years between 1987 and 1993 (NFSI I) and again between 2006 and 2008 (NFSI II). Here, we used data from 1865 NFSI I plots and 1813 NFSI II plots (Fig. 1). The resampling at the same plots indicates a paired sampling schema. In reference to the NFSI II, 624 plots were not resampled at the original NFSI I plots. On the new federal statespecific inventory grid, 577 new plots were established for sampling.

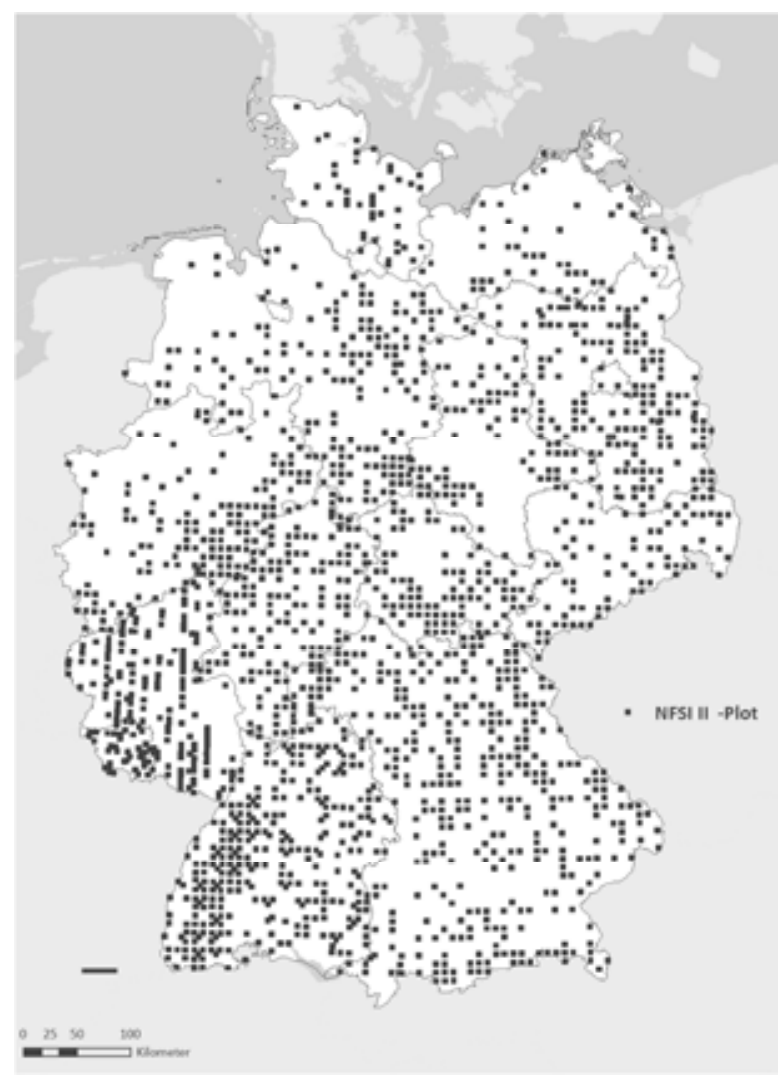

Fig. 1. Spatial distribution of National Soil Inventory plots in Germany.

\section{Soil sampling}

The NFSI II was carried out according to a new manual (Wellbrock et al. 2006) based on the German manuals of soil mapping and on the manual from the BMELV (1990) to ensure the comparability of soil sampling. The standard methods for sampling soils at the NFSI-plots involve 8 satellite samples, with a soil profile from the centre of a plot. All 8 samples were mixed to one sample with had been analysed to reduce soil heterogeneity. The sampling of the organic layer was carried out by mixed samples at 8 satellites with metal frames of different sizes. By the first inventory branches and cones were not sampled, however, all fractions were sampled with the NFSI II. The subsequent partition of the coarse fraction of the organic layer was set at a diameter of $>20 \mathrm{~mm}$. Sampling of mineral soil was conducted at the profile in the depth $0-5 \mathrm{~cm}$, $5-10 \mathrm{~cm}, 10-30 \mathrm{~cm}, 30-60 \mathrm{~cm}$ and $60-90 \mathrm{~cm}$.

\section{Estimation of soil carbon stocks}

Carbon stocks for the organic layer and the mineral soil down to a depth of $30 \mathrm{~cm}$ were estimated according to methods presented by Grüneberg et al. (2014). Carbon stocks down to $90 \mathrm{~cm}$ of the mineral soil were obtained by summing up the individual depths increments. If the lowest depth level was only partially included within 0 - $90 \mathrm{~cm}$ carbon stocks were proportionately calculated. Organic soils or strongly anthropogenic transformed soils were not included in the analysis since the sample number was too small.

Initially, the content of the fine-earth fraction was calculated as a function of drybulk density and the content of the coarse-soil fraction [Eq. 1, 2]. The values were determined by the Federal Forest Research Stations according to the methods of the expert committee on Forest Analysis (GAFA 2006). The Federal State Forest Research Stations delivered either dry density of the fine-earth fraction $\left(\mathrm{g} \mathrm{cm}^{-3}\right)$ or the dry bulk density $\left(\mathrm{g} \mathrm{cm}^{-3}\right)$ as well as the coarse-soil fraction (Vol. \%) or the coarse-soil stocks $\left(\mathrm{t} \mathrm{ha}^{-1}\right)$ to the national database. Those variables have to be continuous for at least $90 \mathrm{~cm}$.

$$
C F F_{i}=B D_{F E_{i}} * D_{i} *\left(1-\frac{V C F_{i}}{100}\right) * 100
$$

$C F F$ - weight of the fine-earth fraction; $B D_{F E}-$ dry bulk density of the fine-earth fraction, $D$ - Depth; $V C F$ - volume of the coarse-soil fraction

or

$$
C C F_{i}=B D_{g} * D_{i}^{*} 100-C C F_{i}
$$

$C C F$ - weight of the coarse-soil fraction; $B D_{t}-$ dry bulk density of the gross soil.

The organic carbon concentration was determined by the methods of GAFA (2006) measuring the total amount of carbon in consideration of inorganic $C$. For soils without carbonates it was assumed that organic and inorganic carbon is equal. 
Site-related carbon stocks down to a depth of $90 \mathrm{~cm}$ of the mineral soil were estimated by applying weighting factors due to different raster densities of the federal states plot grid inventory sites. Weighting factors were derived by calculating the proportion of the federal state forest area in relation to Germany's forest area that were divided by the number of appropriate inventory plots in each federal state [Eq. 3].

$$
w l=\frac{A l}{\sum_{l=1}^{16} A l} * \frac{1}{n l}
$$

with

$w l$-weighting factor of the inventory plots of the federal state l, $A l$-forest area of the federal state l, $n l$ - number of plots within a federal state $\mathrm{l}$.

CORINE land cover data from 1990 and 2006 was used to estimate the proportion of the federal state forest area in relation to Germany's forest area (EEA 2010a; b).

\subsection{National Forest Inventory}

\subsubsection{Sampling methods}

The German National Forest Inventory (NFI) was carried out in the years

- 1986 to 1987 (NFI 1987) only in the old federal states and West-Berlin,

- 2001 to 2002 (NFI 2002) in the whole country and

- 2011 to 2012 (NFI 2012) in the whole country,

comprising close to 60,000 forest sampling plots and 420,000 trees (Fig. 2). In the so called Inventory Study in the year 2008 on a $8 \mathrm{~km} \times 8 \mathrm{~km}$ subsample of the NFI grid all relevant parameters were measured within one year to derive the carbon stock stored in forests in the beginning of the $1^{\text {st }}$ commitment period of the Kyoto-protocol. The NFI is a terrestrial sample with permanent sampling points. The samples are distributed in a systematic $4 \mathrm{~km} \times$ $4 \mathrm{~km}$ basic grid. But in $54 \%$ of the area there is a double or fourfold sampling density. Each sampling unit is a cluster of four plots (or less in the near of country or sampling strata boarders) located at the corners of a $150 \mathrm{~m} \times$ $150 \mathrm{~m}$ square.

For the selection of sample tress with a diameter larger than $7 \mathrm{~cm}$ at breast height (DBH), angle-count sampling is used. For smaller trees there are installed two sample circles with radius of $1 \mathrm{~m}$ and $2 \mathrm{~m}$. Deadwood with a minimum diameter of $10 \mathrm{~cm}$ is assed in sample circles with $5 \mathrm{~m}$ radius. Overview information about the sampling methods of the German NFI can be found for example in Polley et al. 2010. A field manual (BMELV 2011a) gives detailed instruction for the data collection.

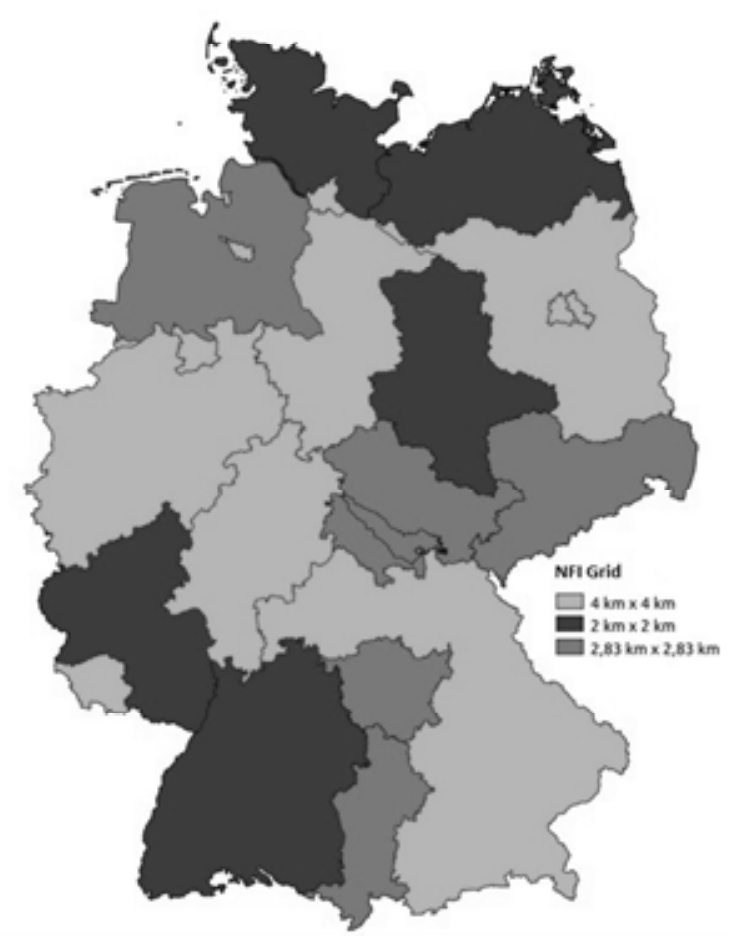

Fig. 2. Sampling grid density of the German National Forest Inventory 2012.

\subsection{Estimation of carbon stocks}

\subsubsection{Above- and below-ground living tree biomass}

First the above- and below-ground living tree biomass is estimated by means of biomass functions derived from the data of the National Forest Inventory, described in Röhling et al. (2016). Within the integrated model for estimating the above-ground biomass on single tree level the predictors DBH, height and the diameter in one third of the tree height are used. This integrated model consists of four allometric (after Marklund) functions for different size classes of trees with continuous transition between these size classes. To estimate the below-ground biomass on single tree level only the DBH acts as a predictor. The coefficients of these functions are specific for five tree species groups: spruce, pine, beech, oak and broadleaved tree species with short life span. Further background and comparisons to other estimation methods about the above and below ground biomass functions can be found in Riedel \& Kändler (2017) and in Neubauer et al. 2015 as well as in Chapter 6.4.2.2.4 of the NIR 2017 (FEA 2017). Then a value of 0.5 has been applied for conversion of biomass into carbon stocks. 


\subsubsection{Biomass of deadwood}

Since the NFI 2002 the carbon stock in dead wood greater than $20 \mathrm{~cm}$ is recorded. In addition dead wood between 10 and $20 \mathrm{~cm}$ is measured for purposes of GHG reporting pursuant to the IPCC Guidelines 2006 since the Inventory Study 2008. The relationship between both subpopulations a) pieces between $10 \mathrm{~cm}$ and $20 \mathrm{~cm}$ and b) pieces greater than $20 \mathrm{~cm}$ was extrapolated to the inventory period 2002 - 2008 to estimate the carbon stock for small dead wood according to the IPCC Guidelines. Within the NFI the sampled dead wood pieces, stumps or dead standing trees were distinguished into three main tree-species groups: conifers, deciduous trees (other than oaks) and oaks. In addition, dead wood was classified into a total of four decomposition-level categories (BMELV 2010; BMVEL 2001). The biomass of the dead wood stocks for the various relevant decomposition classes, was determined with the wood density figures pursuant to Fraver et al. (2002) for conifers, and with the wood density figures pursuant to Müller-Using \& Bartsch (2009) for both deciduous tree species (other than oak) and oak tree species. An overview of the biomass-expansion factors is presented in Table 1. To convert the so derived biomass in carbon, the conversion factor of 0.5 is used once again.

Table 1. Biomass expansion factors (BEF) for the various tree-species classes and degrees of decomposition separately for conifers and deciduous trees.

\begin{tabular}{lllll}
\hline Type of dead wood & \multicolumn{2}{c}{ Degree of decomposition } & BEF & Source \\
\hline Conifers & 1 & Just died & 0.37 & Fraver et al. 2002 \\
Conifers & 2 & Onset of decomposition & 0.31 & \\
Conifers & 3 & Advanced decomposition & 0.14 & \\
Conifers & 4 & Heavily rotted & 0.12 & \\
\hline Deciduous trees & 1 & Just died & 0.58 & Müller-Using \& \\
Deciduous trees & 2 & Onset of decomposition & 0.37 & Bartsch 2009 \\
Deciduous trees & 3 & Advanced decomposition & 0.21 & \\
Deciduous trees & 4 & Heavily rotted & 0.26 & \\
\hline
\end{tabular}

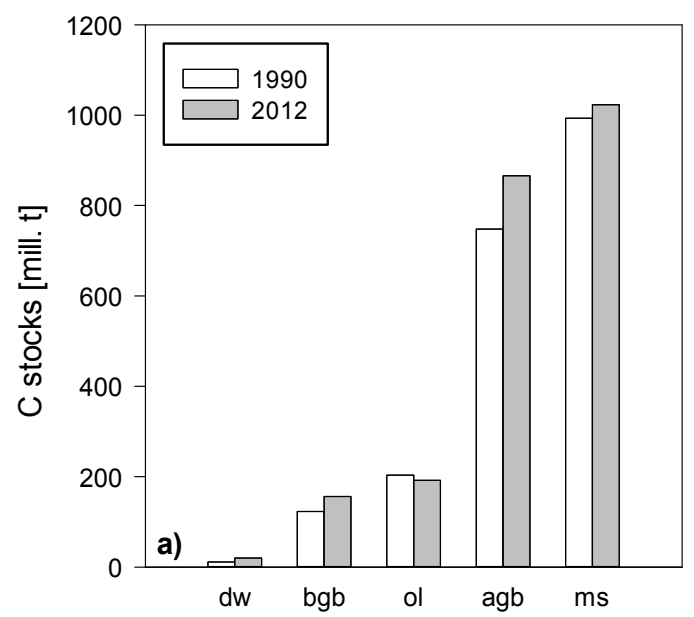

\subsubsection{Estimation of changes in carbon stocks}

For calculations of changes between two time points (the periods 1987-2002, 2002-2008 and 2008-2012), under the continuous forest inventory schema the IPCC stock difference method was used. Therefore estimators for one-phase, stratified sampling were applied according to the NFI sampling design. The total amount of carbon stock changes within a period is divided by the amount of years to derive annual estimates. The annual carbon stock change estimates in dead wood were extrapolated from the inventory period 2002-2008 down to the reference year 1990 .

\section{Results and discussion}

\subsection{Distribution and changes of carbon stocks in the forests in Germany}

Currently, round about 2500 mill. $t$ of carbon are stored in German forests (Fig. 3). In above-ground and belowground biomass $46 \%$ of total carbon stocks are stored, $1 \%$ in dead wood and $53 \%$ in the organic layer together with soil up to $90 \mathrm{~cm}$. Carbon stocks calculated using the data from the NFI 2012 reflect the total forested areas in the country and yield values of approximately 993 mill. $t$ of carbon in the aboveground biomass, 156 mill. t for belowground biomass and 20 mill. $t$ for deadwood (Fig. 3).

A study of Grüneberg et al. (2014) analyzed data of the NFSI and provided an estimate of carbon stocks in the organic layer of $18.8 \pm 0.3 \mathrm{tha}^{-1}$ (192 mill. $\mathrm{t} \mathrm{C}$ ) and in the upper $30 \mathrm{~cm}$ of the mineral soil $61.8 \pm 3.7 \mathrm{t} \mathrm{ha}^{-1}$ (630 mill. $\mathrm{t} \mathrm{C}$ ). The results indicate that the relatively labile carbon pool has remained constant over the period between the inventories since the organic layer comprised $19.0 \pm 0.3 \mathrm{t} \mathrm{C} \mathrm{ha}^{-1}$ (203 mill. t C) at the NFSI I,

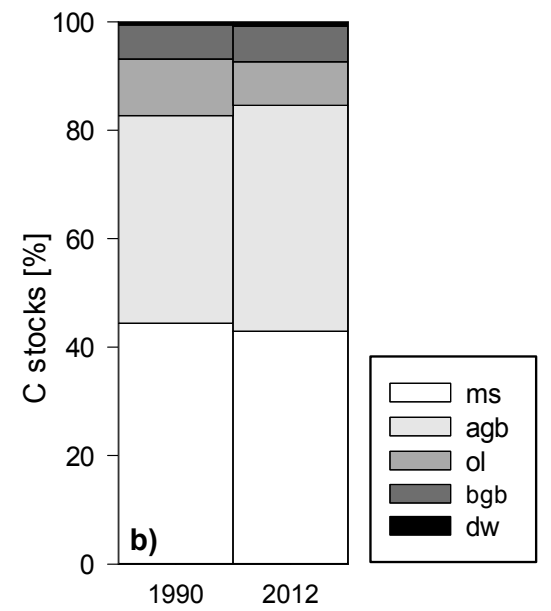

Fig. 3. Distribution of absolute carbon pools in forest ecosystems (a) and relative contribution of the components to total carbon pools (b) in Germany's forests in 1990 and 2012.

Abbreviations of forest ecosystem carbon pools: $\mathrm{dw}$ - dead wood, bgb - below-ground biomass, ol - organic layer*, agb - above-ground biomass, ms - mineral soil*.

*Data was obtained in 2006 by the second National Forest Soil Inventory. 
while the mineral soil down to a depth of $30 \mathrm{~cm}$ stored $55.6 \pm 3.4 \mathrm{t} \mathrm{C} \mathrm{ha}^{-1}$ (595 mill. t C) at the NFSI I. Carbon stocks down to $90 \mathrm{~cm}$ of the mineral soil showed a different development. Estimates of carbon stocks down to a depth of $90 \mathrm{~cm}$ resulted in $84.2 \pm 2.0 \mathrm{t} \mathrm{ha}^{-1}$ (866 mill. t C) and $99.1 \pm 1.8 \mathrm{tha}^{-1}(1,023$ mill. $\mathrm{tC})$ at the first and second NFSI, respectively. The carbon storage is much higher in the upper $30 \mathrm{~cm}$ of the mineral soil than in the soil below. In $60-90 \mathrm{~cm}$ forests soils carbon decrease within the inventories (Grüneberg et al. 2017).

There might be various reasons due to changing impact factors as decreasing atmospheric deposition of acidifying compounds, liming, or large scale forest conversation (Wellbrock et al. 2016). A quarter of the plots have been limed since NFSI I (Grüneberg et al. 2016a). Compared with NFI 2002 the NFI 2012 showed that in German forests growth more broadleaved trees (https://bwi.info). It has been shown that broadleaved forests and limed plots store more carbon (Grüneberg et al. 2016b). A lower $\mathrm{C} / \mathrm{N}$ ratio of broadleaves leaded to a better humus layer status. Liming or higher $\mathrm{pH}$ values might result in leaching carbon from humus layer to upper mineral soil. On a national scale results showed a heterogeneous pattern too (Grüneberg et al. 2014). Changes were particular significant in northern Germany, whereas the changes in most parts of southern Germany were negligible (Grüneberg et al. 2014).Actually, within the Kyotoobligation of reporting soil will be reported up to $30 \mathrm{~cm}$. Results of the NFSI showed that approximately 0.90 mill. $\mathrm{t} \mathrm{C} \mathrm{ha-1}$ are stored in forests soils. Soil carbon stocks within this depth increase about $0.4 \mathrm{tha}^{-1} \mathrm{yr}^{-1}$. and in the biomass the increment is about $1.0 \mathrm{t} \mathrm{C} \mathrm{ha}^{-1} \mathrm{yr}^{-1}$. Closer inspection revealed a slight increase in carbon stocks in deadwood since the 2002 inventory. The increase in carbon stocks in biomass is substantially greater. Since 2008 , an annual increase of close to 12 mill. $\mathrm{t} C$ has been documented. For German forest an inventory in 2008 showed that 1.43 mill. $\mathrm{t} \mathrm{C} \mathrm{ha}^{-1}$ were fixed in forests stand. This is $4.7 \mathrm{tC} \mathrm{ha}^{-1}$ more than in 2002 (Dunger et al. 2009). However, the net-sink rate of forests stands could decrease in the next years (Krug \& Köhl 2010) because wood products became more attractive.

\subsection{Impact on carbon sequestration}

The impact of forest management and indirect anthropogenic activities on the carbon dynamic in forest ecosystems is high. Various studies have shown a significant influence of tree species selection and accompanied forest stand composition on carbon stocks (LadegaardPedersen et al. 2005; Prietzel \& Bachmann 2012). Forest management practices such as drainage, thinning, timber harvesting and liming can also affect soil carbon dynamics (Johnson et al. 2002; Nave et al. 2010). Admittedly, investigations of liming induced effects on carbon stock changes have revealed contradictory results. On the one hand, it has been shown that after the application of lime the decomposition of the organic layer increased accompanied by an accumulation of carbon in the mineral soil (Andersson \& Nilsson 2001; Evers et al. 2008). On the other hand, various studies have demonstrated that a long-lasting decrease ranging from weeks up to one year followed by the initial increase in soil respiration after liming (Illmer \& Schinner 1991; Melvin et al. 2013). Other studies suggest an impact of nitrogen $(\mathrm{N})$ deposition on carbon sequestration in forest but the results are highly uncertain and vary by two orders of magnitude (de Vries et al. 2009; Janssens et al. 2005). The increase in nitrogen deposition on forests over a longer time period may reduce the decomposition of organic matter. Increased organic matter input in soil through enhanced aboveground biomass productivity or increased recalcitrance of nitrogenenriched litter may lead to reduced long-term decomposition rates of organic matter (de Vries et al. 2009) but on the other hand high nitrogen deposition lead to increasing biomass in nitrogen limited forest ecosystems.

Tree growth may reduce the greenhouse effect due to tree assimilation of $\mathrm{CO}_{2}$. Living biomass of beech stands store $3.3 \mathrm{tha}^{-1} \mathrm{yr}^{-1}$ and spruce stands $3.2 \mathrm{tha}^{-1} \mathrm{yr}^{-1}$ carbon. The increment of spruce is higher than those of beech, but beech has a higher wood density (Kollmann 1982). If one considers increment and drain (net change) respectively beech stored $0.98 \mathrm{t} \mathrm{ha}^{-1} \mathrm{yr}^{-1}$ while spruce carbon storage is $-0.39 \mathrm{tha}^{-1} \mathrm{yr}^{-1}$. The negative development in spruce stands can be explained by intensive harvesting activities Currently in beech stands $127 \mathrm{t} \mathrm{ha}^{-1}$ carbon are stored in the aboveground biomass and 101 tha $^{-1}$ in spruce stands. A sustainable forest management with more beech stands improves to carbon budget of forests. The release of $\mathrm{CO}_{2}$ can be avoided or reduced as a consequence of carbon storage in forests.

\subsection{Forests and wood products are carbon sinks}

As proved in the National Inventory Report forests in Germany act as a carbon sink each year since 1990 . Thus more carbon was sequestered than released, for example in timber harvest. The estimate of annual carbon sequestration including $\mathrm{CO}_{2}$-release due usage of timber (net change) is currently 58 mill. $t$ (FEA 2017). To date, the annual greenhouse gas reporting has included only carbon sequestration - material use of wood and its contribution to annual $\mathrm{CO}_{2}$ balance is considered. However, this approach is misleading the material use of wood involves the transfer of a quantity of carbon from trees to the wood products-like forests, these products thus serve as carbon sink. Production of energy from the renewable resource also replaces fossil fuel sources (the substitution effect). Between 2005 and 2009 in average close to 15 mill. $t$ of carbon was sequestered in wood products and approximately another 8 mill. $t$ was saved through 
energy substitution annually (Rüter 2011). The potential of forests as carbon sinks is therefore even greater than previously indicated in the reports.

\section{Conclusions}

The representative samples of the NFI as well as the NFSI and their repetitions cover entire Germany and are high quality data to estimate carbon stocks and carbon stock changes in biomass, dead wood, litter and soils up to a depth of $90 \mathrm{~cm}$ according to the Kyoto reporting obligations and further relationship- impact studies. Since there are only few comparable qualitative and quantitative data, especially for soils, the analysis of these data sets will provide results that will helpful to understand carbon storage of forests. Furthermore, the reporting obligations create additional opportunities for quality assessment of the inventory data and set new standards on sampling methods as well as evaluation approaches. Our results show that the carbon pools biomass, dead wood and mineral soils in the German forests act as a carbon sink with an increasing carbon storage within the reporting time. The forest management and atmospheric deposition of sulphur, nitrogen and $\mathrm{CO}_{2}$ has changed in the second half of the $20^{\text {th }}$ century. The percentage of broadleaves increased in the same time. Furthermore many forests had been limed. This development protects the supply of organic carbon. This way, management may lead temporarily to a higher root penetration into the soil and thus lead to higher carbon entries. Another cause of the high immobilization rates could be that carbon poor soils are not saturated with carbon and which results in an upward trend until a steady state situation is reached. All immobilization rates are quite high. Both inventories are more or less 5 to 15 years old. In 2017 a carbon inventory is carried out on a $8 \mathrm{~km}$ by $8 \mathrm{~km}$ sub-grid of the NFI to assess the current carbon stock in living biomass and dead wood. The next NFI will be conducted in $2021 / 2022$. The next soil Inventory is planned to conduct in 2023-2025. Then, we can see how processes in forests will go on. In addition process-oriented research would be necessary to detect causes of changes.

\section{Acknowledgement}

All fieldwork had been done and financed by the federal states in Germany. The Federal Ministry of Food, Agriculture and Costumer Protection financed the Federal Coordination and Federal Evaluation.

\section{References}

Batjes, N. H., 1996: Total carbon and nitrogen in the soils of the world. European Journal of Soil Science, 47:151-163.
Bellamy, P. H., Loveland, P. J., Bradley, R. I., Lark, R. M., Kirk, G. J. D., 2005: Carbon losses from all soils across England and Wales 1978-2003. Nature, 437:245-248.

BMELV,1990:BundesweiteBodenzustandserhebungim Wald (BZE). Arbeitsanleitung. Bundesministerium für Ernährung, Landwirtschaft und Forsten, Bonn. $158 \mathrm{p}$.

BMELV (Bundesministerium für Verbraucherschutz, Ernährung und Landwirtschaft) (Hrsg.), 2001: Aufnahmeanweisung für die Bundeswaldinventur II (2001-2002), 2. korrigierte, überarbeitete Ausgabe, Mai 2001, Bonn, 108 p.

BMELV (Bundesministerium für Ernährung, Landwirtschaft und Verbraucherschutz) (Hrsg.), 2005. Die zweite Bundeswaldinventur - BWI: Der Inventurbericht. Bonn, $231 \mathrm{p}$.

BMELV (Bundesministerium für Ernährung, Landwirtschaft und Verbraucherschutz) (Hrsg.), 2010: Aufnahmeanweisung für die Inventurstudie $2008 \mathrm{im}$ Rahmen der Treibhausgasberichterstattung. 2. korrigierte, überarbeitete Aufl., Bonn, 60 p.

BMELV (a) (Bundesministerium für Ernährung, Landwirtschaft und Verbraucherschutz) (Hrsg.), 2011: Survey Instruction fort he $3^{\text {rd }}$ National Forest Inventory (2011-2012). $2^{\text {nd }}$ revised version, $108 \mathrm{p}$.

BMELV (b) (Bundesministerium für Ernährung, Landwirtschaft und Verbraucherschutz) (Hrsg.), 2011: Forest strategy, $36 \mathrm{p}$.

Bonan, G. B., 2008: Forests and climate change: Forcings, feedbacks, and the climate benefits of forests. Science, 320:1444-1449

Brady, N. C., Weil, R. R., 2007: Carbon Balance in the Soil-Plant-Atmosphere System. Pearson, 980 p.

De Vries, W., Solberg, S., Dobbertin, M., Sterba, H., Laubhann, D., van Oijen, M. et al., 2009: The impact of nitrogen deposition on carbon sequestration by European forests and heathlands. Forest Ecology and Management, 258:1814-1823.

Dunger, K., Stümer, W., Oehmichen, K., Riedel, T.,Ziche, D., Grüneberg, E. et al., 2014: Nationaler Inventarbericht Deutschland. Kapitel 7.2 Wälder. Umweltbundesamt (FEA), Climate Change, 28:517-564.

EEA, 2010a: Raster data on land cover for the CLC 1990 inventory. European Environment Agency, Copenhagen.

EEA, 2010b: Raster data on land cover for the CLC 2006 inventory. European Environment Agency, Copenhagen.

Evers, J., Dammann, I., Noltensmeier, A., Nagel, R.-V, 2008: Auswirkungen von Bodenschutzkalkungen auf Buchenwälder (Fagus sylvatica L.). In Ergebnisse angewandter Forschung zur Buche. Beiträge aus der NW-FVA, edited by NW-FVA. Göttingen. 
FEA, 2017: National Inventory Report for the German Greenhouse Gas Inventory 1990-2015. Submission under the United Nations Framework Convention on Climate Change and the Kyoto Protocol 2017. Federal Environment Agency, Dessau-Roßlau, 1085 p.

Fraver, S., Wagner, R. G., Day, M., 2002: Dynamics of coarse woody debris following gap harvesting in the Acadian forest of central Maine, USA. Canadian Journal of Forest Research, 32:2094-2105.

GAFA, 2006: Handbuch Forstliche Analytik. Eine Loseblatt-Sammlung der Analysemethoden im Forstbereich, Gutachterausschuss Forstliche Analytik. Bundesministerium für Ernährung und Landwirtschaft, Berlin.

Grüneberg, E., Ziche, D., Wellbrock, N., 2014: Organic carbon stocks and sequestration rates of forests soils in Germany. Global Change Biology, 20:2644-2662.

Grüneberg, E., Aydin,C. T., Baritz,R., Milbert, G. 2016a: Die Waldböden und ihre Einflußfaktoren. In: Wellbrock, N., Bolte, A., Flessa, H.: Dynamik und räumliche Muster forstlicher Standorte in Deutschland. Johann Heinrich von Thünen-Institut, Braunschweig, Thünen Report 43.

Grüneberg, E., Riek, W., Schöning, I., Evers, J., Hartmann, P. et al., 2016b: Kohlenstoffvorräte und deren zeitliche Veränderungen in Waldböden. In: Wellbrock, N., Bolte, A., Flessa, H.: Dynamik und räumliche Muster forstlicher Standorte in Deutschland. Johann Heinrich von Thünen-Institut, Braunschweig, Thünen Report 43.

Hagedorn, F., Spinnler, D., Bundt, M., Blaser, P., Siegwolf, R., 2003: The input and fate of new $C$ in two forest foils under elevated $\mathrm{CO}_{2}$. Global Change Biology, 9:862-872. IPCC (Intergovernmental Panel on Climate Change), 2003: Good Practice Guidance for Land Use, Land-Use Change and Forestry, vi +307 p.

Illmer, P., Schinner, F., 1991: Effects of lime and nutrient salts on the microbiological activities of forest soils. Biology and Fertility of Soils, 11:261-266.

Janssens, I. A., Freibauer, A., Schlamadinger, B., Ceulemans, R., Ciais, P., Dolman, A. J . et al., 2005: The carbon budget of terrestrial ecosystems at country-scale - a European case study. Biogeosciences, 2:15-26.

Jobbagy, E. G., Jackson, R. B., 2000: The vertical distribution of soil organic carbon and its relation to climate and vegetation. Ecological Applications, 10: 423-436.

Johnson, D. W., Knoepp, J. D., Swank, W. T., Shan, J., Morris, L. A., Van Lear, D. H. et al., 2002: Effects of forest management on soil carbon: results of some long-term resampling studies. Environmental Pollution, 116:201-208.

Kollmann, F. 1982: Technologie des Holzes und der Holzwerkstoffe. Springer-Verlag, Berlin, Heidelberg, New York.
Kowalski, A. S., Loustau, D., Berbigier, P., Manca, G., Tedeschi, V., Borghetti, M. et al., 2004: Paired comparisons of carbon exchange between undisturbed and regenerating stands in four managed forests in Europe. Global Change Biology, 10:1707-1723.

Krug, J., Köhl, M., 2010: Bedeutung der deutschen Forstwirtschaft in der Klimapolitik. AFZ-Der Wald, 65:30-33.

Ladegaard-Pedersen, P.; Elberling, B., Vesterdal, L., 2005: Soil carbon stocks, mineralization rates, and $\mathrm{CO}_{2}$ effluxes under 10 tree species on contrasting soil types. Canadian Journal of Forest Research, 35:1277-1284.

Liski, J., Perruchoud, D., Karjalainen, T., 2002: Increasing carbon stocks in the forest soils of western Europe. Forest Ecology and Management, 169:159-175.

Magnani, F., Mencuccini, M., Borghetti, M., Berbigier, P., Berninger, F., Delzon, S. et al., 2007: The human footprint in the carbon cycle of temperate and boreal forests. Nature, 447:849-851.

Melvin, A. M.; Lichstein, J. W., Goodale, C. L., 2013: Forest liming increases forest floor carbon and nitrogen stocks in a mixed hardwood forest. Ecological Applications, 23:1962-1975.

Müller-Using, S., Bartsch, N., 2009: Decay dynamic of coarse and fine woody debris of a beech (Fagus sylvatica L.) forest in Central Germany. European Journal of Forest Research, 128:287-296.

Nave, L. E.; Vance, E. D.; Swanston, C. W., Curtis, P. S., 2010: Harvest impacts on soil carbon storage in temperate forests. Forest Ecology and Management, 259:857-866.

Neubauer, M., Demant, B., Bolte, A., 2015: Einzelbaumbezogene Schätzfunktionen zur unterirdischen Biomasse der Wald-Kiefer (Pinus sylvestris L.). Forstarchiv, 86:42 - 47 .

Polley, H., Schmitz, F., Hennig, P., Kroiher, F., 2010: National forest inventories: chapter 13, Germany. In: Tomppo, E., Gschwantner, T., Lawrence, M., McRoberts, R. E. (eds.): National forest inventories: pathways for common reporting. Berlin: Springer, p. 191-214.

Prietzel, J., Bachmann, S., 2012: Changes in soil organic $\mathrm{C}$ and $\mathrm{N}$ stocks after forest transformation from Norway spruce and Scots pine into Douglas fir, Douglas fir/spruce, or European beech stands at different sites in Southern Germany. Forest Ecology and Management, 269:134-148.

Riedel, T., Kändler, G., 2017: Nationale Treibhausgasberichterstattung: Neue Funktionen zur Schätzung der oberirdischen Biomasse am Einzelbaum. Forstarchiv, 88:31-38.

Riedel, T., Polley, H., Klatt, S., 2016: Germany. In:Vidal, C., Alberdi, I., Hernández, L., Redmond, J. J. (eds.): National forest inventories: assessment of wood availability and use. Cham: Springer International Publ., p. 405-421. 
Röhling, S., Dunger, K., Kändler, G., Klatt, S., Riedel, T., Stümer, W., 2016: Comprarion of calculation methods for estimating annual carbon stock change in German forests under forest management in the German greenhouse gas inventory. Carbon Balance and Management, 11:12.

Rüter, S., 2011: Welchen Beitrag leisten Holzprodukte zur $\mathrm{CO}_{2}$-Bilanz. AFZ Der Wald, 66:15-18.

Six, J., Callewaert, P., Landers, S., Gryze, S. D., Morris, S. J., Gregorich, R. G. et al., 2002: Measuring and understanding carbon storage in afforested soils by physical fractionation. Soil Science Society of America Journal, 66:1981-1987.

Spieker, H., Mielikäinen, K., Köhl, M., Skovsgaard, J. P. (eds.), 1996: Growth Trends in European Forests. Berlin, Springer.

Tomppo, E., Gschwantner, T., Lawrence, M., McRoberts, R. E., 2010: National Forest Inventories: Pathways for Common Reporting. Springer, $612 \mathrm{p}$.

Vidal, C., Alberdi, I. A., Hernández Mateo, L., Redmond, J. J., 2016: National Forest Inventories: Assessment of Wood Availability and Use. Springer International Publishing, $845 \mathrm{p}$.
Wellbrock, N., Bolte, A., Flessa, H. (eds.), 2016: Dynamik und räumliche Muster forstlicher Standorte in Deutschland. Thünen Report, 43:550.

Wellbrock, N., Grüneberg, E., Stümer, W., Rüter, S., Ziche, D., Dunger, K. et al., 2014: Wälder in Deutschland speichern Kohlenstoff. AFZ Wald, 69:38-39.

Wellbrock, N., Aydin, C. T., Block, J., Bussian, B., Deckert, M., Diekmann, O. et al., 2006: Bodenzustandserhebung im Wald (BZE II) Arbeitsanleitung für die Außenaufnahmen. Bundesministerium für Ernährung, Landwirtschaft und Verbraucherschutz. Berlin.

Wirth, C., Schumacher, J., Schulze, E.-D., 2004: Generic biomass functions for Norway spruce in Central Europe-A meta-analysis approach toward prediction and uncertainty estimation, Tree Physiology, 24:121-139.

Wolff, B., Riek,W., 1996: Deutscher Waldbodenbericht 1996-Ergebnisse der bundesweiten Bodenzustandserhebung in Wald (BZE) 1987-1993. Bundesministerium für Ernährung, Landwirtschaft und Forsten. Bonn, $144 \mathrm{p}$. 